Article

\title{
Identification and Characterization of NPR1 and PR1 Homologs in Cymbidium orchids in Response to Multiple Hormones, Salinity and Viral Stresses
}

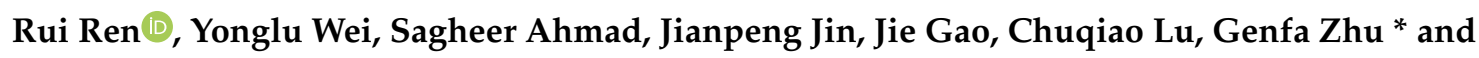 \\ Fengxi Yang * \\ Guangdong Key Laboratory of Ornamental Plant Germplasm Innovation and Utilization, Environmental \\ Horticulture Research Institute, Guangdong Academy of Agricultural Sciences, Guangzhou 510640, China; \\ renruinjau@163.com (R.R.); hjyylab@126.com (Y.W.); sagheerhortii@gmail.com (S.A.); \\ 13424050551@163.com (J.J.); gaojie@gdaas.cn (J.G.); chuqiaolu18@163.com (C.L.) \\ * Correspondence: genfazhu@163.com (G.Z.); yangfengxi@gdaas.cn (F.Y.)
}

Received: 25 January 2020; Accepted: 12 March 2020; Published: 13 March 2020

\begin{abstract}
The plant nonexpressor of pathogenesis-related 1 (NPR1) and pathogenesis-associated 1(PR1) genes play fundamental roles in plant immunity response, as well as abiotic-stress tolerance. Nevertheless, comprehensive identification and characterization of NPR1 and PR1 homologs has not been conducted to date in Cymbidium orchids, a valuable industrial crop cultivated as ornamental and medicinal plants worldwide. Herein, three NPR1-like (referred to as CsNPR1-1, CsNPR1-2, and CsNPR1-3) and two PR1-like (CsPR1-1 and CsPR1-2) genes were genome-widely identified from Cymbidium orchids. Sequence and phylogenetic analysis revealed that CSNPR1-1 and CSNPR1-2 were grouped closest to NPR1 homologs in Zea mays (sharing 81.98\% identity) and Phalaenopsis (64.14\%), while CsNPR1-3 was classified into a distinct group with Oryza sativa NPR 3 (57.72\%). CsPR1-1 and CsPR1-2 were both grouped closest to Phalaenopsis PR1 and other monocot plants. Expression profiling showed that CSNPR1 and CsPR1 were highly expressed in stem/pseudobulb and/or flower. Salicylic acid (SA) and hydrogen peroxide $\left(\mathrm{H}_{2} \mathrm{O}_{2}\right)$ significantly up-regulated expressions of CsNPR1-2, CsPR1-1 and CsPR1-2, while CsNPR1-3, CsPR1-1 and CsPR1-2 were significantly up-regulated by abscisic acid (ABA) or salinity $(\mathrm{NaCl})$ stress. In vitro transcripts of entire Cymbidium mosaic virus (CymMV) genomic RNA were successfully transfected into Cymbidium protoplasts, and the CymMV infection up-regulated the expression of CsNPR1-2, CsPR1-1 and CsPR1-2. Additionally, these genes were transiently expressed in Cymbidium protoplasts for subcellular localization analysis, and the presence of SA led to the nuclear translocation of the CsNPR1-2 protein, and the transient expression of CSNPR1-2 greatly enhanced the expression of CsPR1-1 and CsPR1-2. Collectively, the CsNPR1-2-mediated signaling pathway is SA-dependent, and confers to the defense against CymMV infection in Cymbidium orchids.
\end{abstract}

Keywords: Cymbidium orchid; Genome-wide identification; Hydrogen peroxide $\left(\mathrm{H}_{2} \mathrm{O}_{2}\right)$; Nonexpressor of pathogenesis-related 1 (CsNPR1); Pathogen-associated 1 (CsPR1); Salicylic acid (SA)-dependent; Cymbidium mosaic virus (CymMV)

\section{Introduction}

The Orchidaceae is one of the largest and the most evolved families of monocot plants [1]. More than 70,000 orchids have been cultivated as ornamental and medicinal plants throughout the world [2]. Cymbidium orchids, best known for their aesthetic appeal and ideal characteristics, are widely distributed and popular in subtropical and tropical Asia [3,4]. However, numerous biotic (fungal, bacterial and viral diseases) and abiotic stresses (drought, salinity, etc.) seriously affect orchid production [5]. For instance, 
Cymbidium mosaic virus (CymMV, Potato virus X) and Odontoglossum ringspot virus (Tobamovirus) are two prevalent viral pathogens infecting orchids that cause chlorosis, necrosis, and dwarfing symptoms on orchid plants, thereby reducing the ornamental and economic value of orchids [6]. Replacing infected plants with virus-free germchit generated through meristem culturing has been widely applied as the main control measure for orchid viral diseases [7,8]. However, orchid tissue culturing is costly, labor-intensive and time-consuming. The long vegetative growth period of orchids also makes it necessary to find a permanent solution for this issue. The introduction of natural and broad-spectrum resistance against pathogens is regarded as the most economical and eco-friendly strategy for plant disease management [9-11].

The nonexpressor of pathogenesis-related 1 (NPR1) plays a key role in multiple signaling pathways in plant immunity [12] and abiotic-stress tolerance [13-15]. More concretely, the NPR1 protein has been demonstrated as an essential regulator of long-lasting and broad-spectrum systemic acquired resistance (SAR) contributing to resistance against fungal, bacterial and viral pathogens $[16,17]$. SAR is induced by systemic changes in endogenous molecules, such as a burst of reactive oxygen species (ROS) and changes in hormonal levels following local infection of pathogens $[18,19]$. When SAR occurs, several pathogenesis-related $(P R)$ genes are active locally at the site of infection and systemically in distal plant tissues [20,21]. The inducible SAR confers broad-spectrum immunity not only to secondary infection but also to other pathogens $[19,22,23]$. Since the first NPR1 protein was identified in Arabidopsis through a mutant screen [24], NPR1-like homologs have been identified from various plant species (Table S1). However, the identification of plant immunity is mostly limited to model plants, including Arabidopsis thaliana, rice (Oryza sativa) and tobacco (Nicotiana spp.). For the species' limitations, little progress on orchid defense and/or tolerance to these pathogenesis stresses has been reported. Chen et al. first identified the orchid PhaNPR1-like and PhaPR1-like genes from Phalaenopsis [25], and a C3HC4-type RING-finger domain-containing transcription factor PhaTF15 was shown to be involved in the regulation of PhaNPR1, PhaPR1, and virus accumulation [26]. Nevertheless, NPR1-like or PR1-like genes have not yet been identified from Cymbidium orchids.

Constitutive expression of NPR1 within wild-type Arabidopsis thaliana ensures a quick response to salicylic acid (SA) [27]. Recent research has demonstrated that NPR1 transduces the SA signal to activate expression of PR genes [28]. NPR1 protein is predominantly oligomeric and sequestered in the cytoplasm in the absence of pathogen infection [16]. Pathogen infections induce the accumulation of SA in both inoculated and systematic leaves of plants. Meanwhile, biphasic change in cellular reduction potentially results in reduction in NPR1 to a monomeric form following pathogen challenges. Acting as a receptor of SA, monomeric NPR1 protein directly binds SA and translocates to the nucleus [29], which is required for the activation of PR gene expression [30]. However, whether the NPR1-dependent SA signaling in orchid plants is conserved in other species remains unclear.

For the first time, we carried out a genome-wide identification of NPR1 and PR1 homologs in Cymbidium orchids. To investigate the involvement of the NPR1-mediated signaling pathway in Cymbidium orchids, the expression of CSNPR1 and CSPR1 genes in response to phytohormones, abiotic salinity stresses and CymMV infection were examined. Additionally, CsNPR1 and CsPR1 genes were transiently expressed in the Cymbidium protoplasts for subcellular localization and gene regulation analysis. Finally, we figured out the NPR1-mediated signaling pathway, which is Salicylic acid-dependent and triggered by CymMV infection in Cymbidium orchids.

\section{Results}

\subsection{Genome-Wide Identification of NPR1 and PR1 Homologs in Cymbidium Orchids}

To identify NPR1 and PR1 homologs in Cymbidium orchids, a local protein BLAST search of homolog sequences from Phalaenopsis and rice was performed against unpublished C. sinense database. Genome-wide identification resulted in three CsNPR1-like (designated CsNPR1-1, CsNPR1-2 and CsNPR1-3) and two CsPR1-like genes (CsPR1-1 and CsPR1-2) being identified from Cymbidium sinense. 
In the full genomic sequence of each CSNPR1 gene, there were three introns and four exons, but only one exon exists in each CsPR1 gene (Figure S1). Sequence analysis revealed that the coding sequences (CDSs) of CsNPR1-1, CsNPR1-2, CsNPR1-3, CsPR1-1 and CsPR1-2 contained 1707, 1668, 1446, 501 and 504 -bp open reading frames, encoding putative proteins of 569, 556, 482, 167 and 168 amino acids, respectively (Figure 1). Domain architecture analysis revealed that CsNPR1 proteins shared conserved broad-complex, tramtrack, bric-a-brac/poxvirus and zinc finger (BTB/POZ) domains, two or three ankyrin repeat (ANK) domains, and an NPR1-like defense protein C domain with other NPR1 homologs (Figure 1A). Putative CsPR1 proteins share a conserved signal peptide (SP) and a sterol carrier protein (SCP) domain with PR1-like proteins in other plant species (Figure 1B).

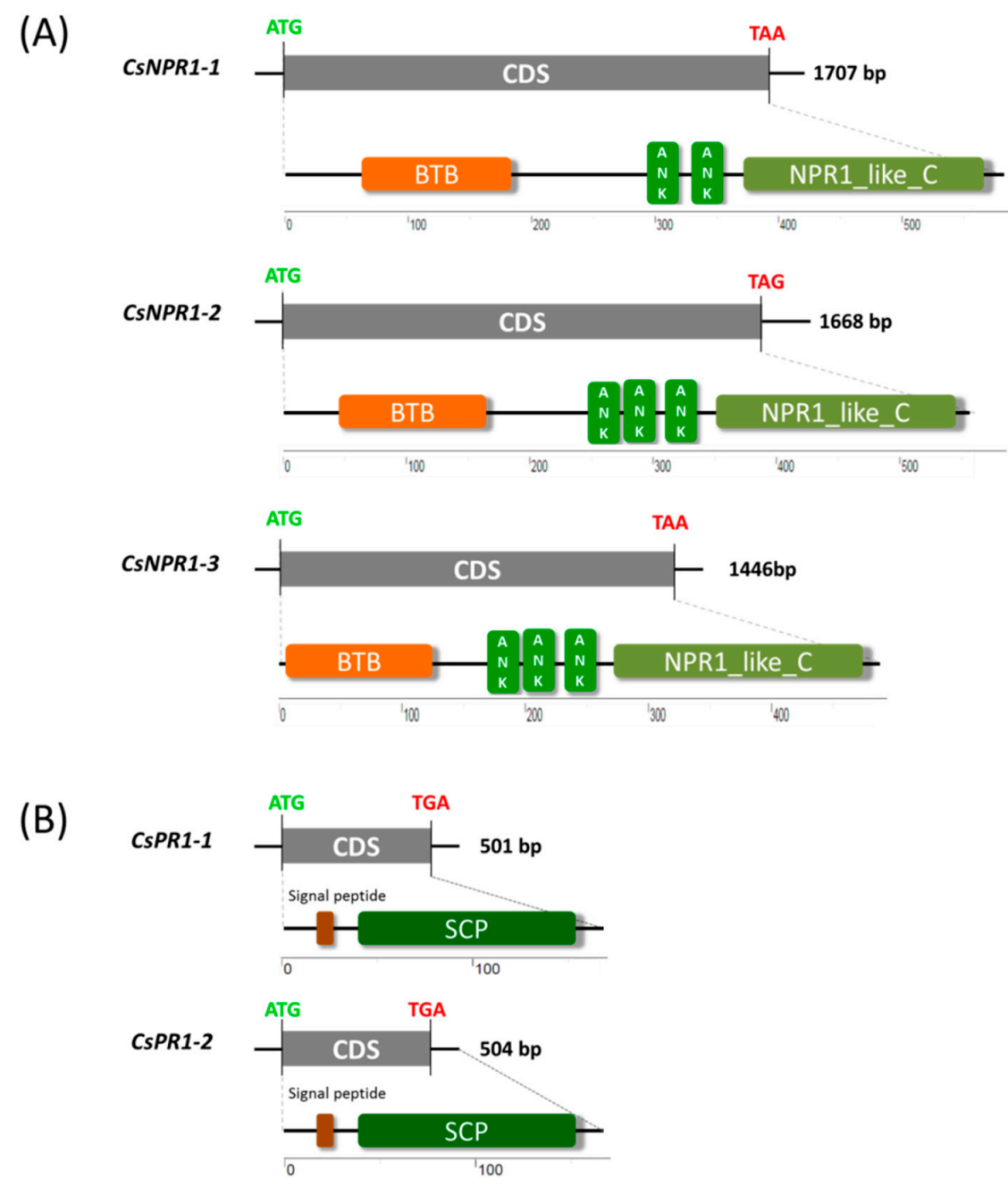

Figure 1. Domain architectures of putative CsNPR1 and CsPR1 proteins in Cymbidium sinense. (A) Putative CsNPR1 proteins share a conserved broad-complex, tramtrack, bric-a-brac/poxvirus and zinc finger (BTB/POZ) domains, two or three ankyrin repeat (ANK) domains, and a NPR1-like defense protein C domain with other NPR1 homologs; (B) CsPR1 proteins share a conserved signal peptide (SP) and a sterol carrier protein (SCP) domain with PR1-like proteins in other plant species.

\subsection{Phylogenetic Analysis and Sequence Alignment of NPR1 and PR1 Homologs}

To investigate the homology between NPR1-like and PR1-like proteins, phylogenetic analysis and sequence alignments were carried out using their full-length deduced amino acid sequences (Tables S1 and S2). Among the three CsNPR1-like homolog proteins, CsNPR1-1 and CsNPR1-2 showed a higher homology (sharing $67.57 \%$ identity), and were the group closest with NPR1 proteins in Zea mays (sharing 81.98\% identity) and Phalaenopsis (64.14\% identity), respectively (Figure 2A). 
However, CsNPR1-3 was classified into a distinct group with the Calotropis procera NPR1 (70.68\% identity) and Oryza sativa NPR1-like protein 3 (NPR3) (57.72\% identity), respectively. The BTB/POZ domains of NPR1-like proteins are highly conserved (Figure S2A). In addition, PR1-like proteins were classified into two major groups, and CsPR1-1 and CsPR1-2 proteins were grouped together with other PR1 proteins from monocots (Figure 2B). Putative CsPR1-1 and CsPR1-2 proteins were highly conserved (99.40\% identity), and formed a distinct subgroup with the Phalaenopsis PR1 protein, sharing $68.67 \%$ and $68.26 \%$ identity, respectively (Figure 2B and Figure S2B).

(A)

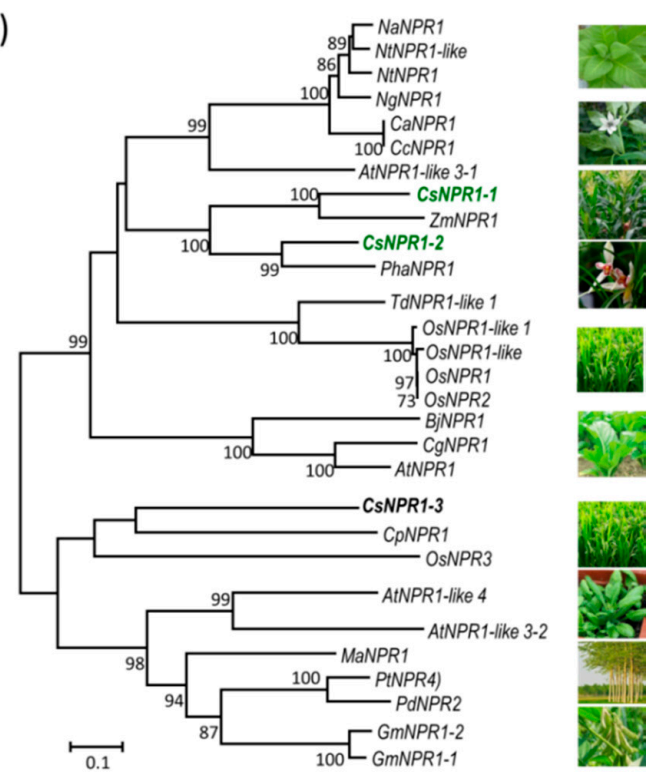

(B)

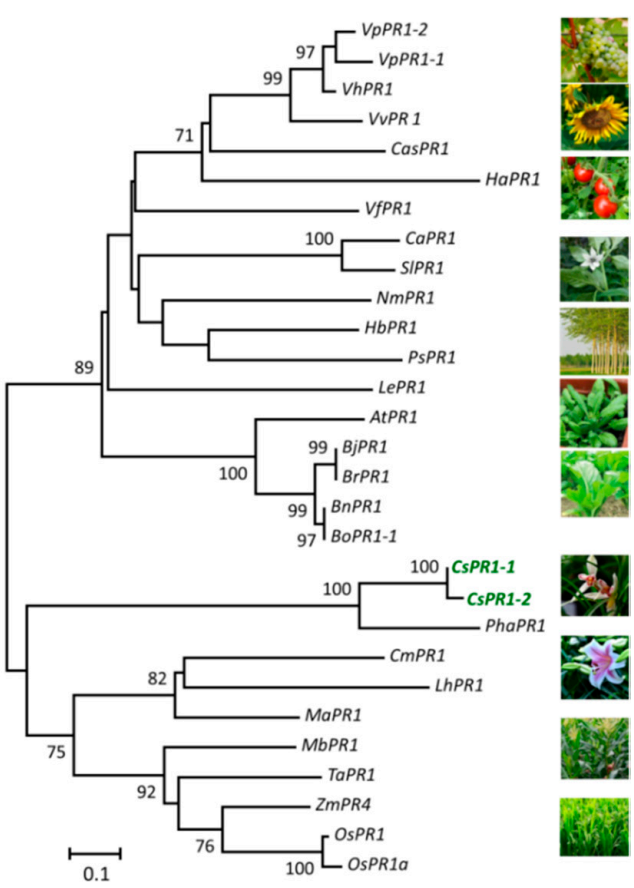

Figure 2. Phylogenetic analyses of CSNPR1 and CsPR1 genes and their homologous in various plant species. The deduced amino acid sequences of (A) NPR1 and (B) PR1 homologs from different plant species were used to construct the phylogenetic trees using the neighbor-joining method with the 1000 bootstrap values indicated. The information for the homologs used in the analysis is listed in Tables S1 and S2. 


\subsection{Tissues/Organs-Specific Expression Analysis of CsNPR1 and CsPR1 Genes}

To characterize the expression patterns of CsNPR1 and CsPR1 genes, the expression profiles of these genes in different tissues/organs (roots, stem/pseudobulb, leaf, flower and pod) (Figure 3A) were evaluated by quantitative reverse-transcription polymerase chain reaction (qRT-PCR). Although they had different relative expression levels, these genes were detectable in various tissues/organs. CSNPR1-1 and CSNPR1-2 showed similar expression patterns regardless of their overall gene expression levels, with the highest expression levels in the stem/pseudobulb followed by flower, while CSNPR1-3 showed the highest expression in flower (Figure 3B). The relative expression levels of CsNPR1-1 and CSNPR1-3 were much lower than that of CsNPR1-2 overall, which indicate that CsNPR1-2 is more active. The expression patterns of the two CsPR1 genes were similar, and both CsPR1-l and CsPR1-2 showed the highest expression levels in flower (Figure 3C). The results showed that CSNPR1 and CsPR1 genes were constitutively expressed in various tissues/organs, with higher expression levels in the plant aerial portion than in others.

(A)

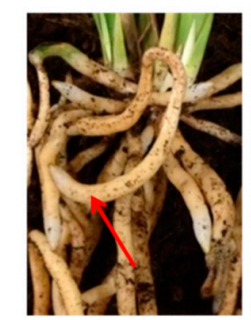

Root

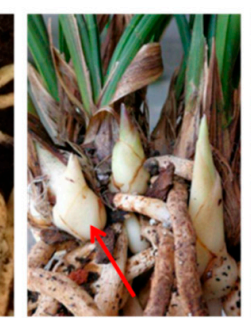

Stem

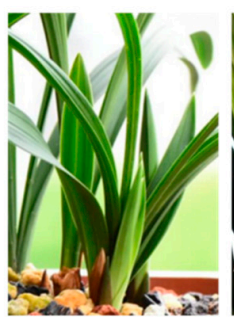

Leaf

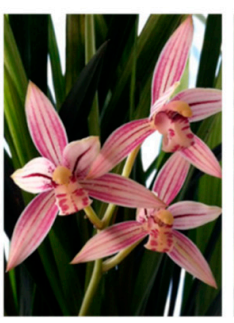

Flower

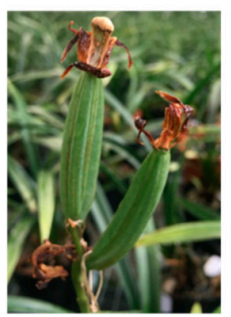

Pod

(B)

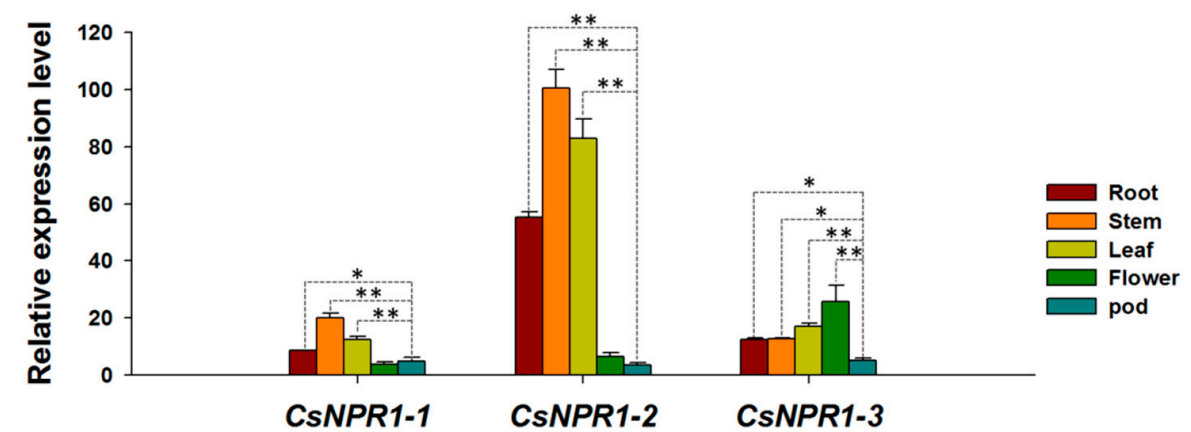

(C)

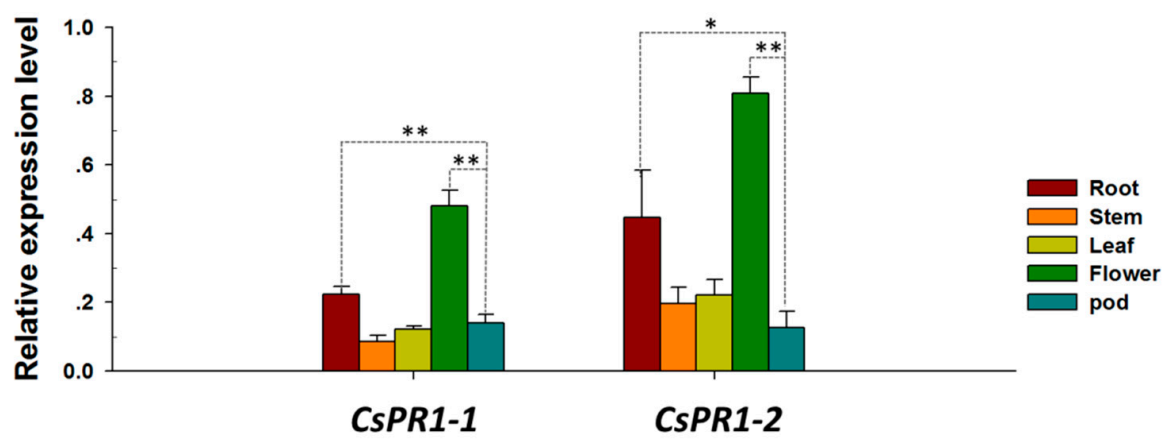

Figure 3. Tissue/organ specific expression analysis of CsNPR1 and CsPR1 genes. (A) Different tissues/organs (root, stem, leaf, flower and pod) were collected for total RNA isolation; and the expression patterns of (B) CsNPR1 and (C) CsPR1 genes were examined by qRT-PCR. Y-axes indicate the relative expression levels; significant difference was assessed by Mann-Whitney U-test and indicated by asterisks; single asterisk $\left(^{*}\right)$ represents $p \leq 0.05$, double asterisk $\left.{ }^{* *}\right)$ represents $p \leq 0.01$; Data are expressed as the mean of three biological replicates, with error bars indicating the SD (standard deviation). 


\subsection{SA and ROS Significantly Upregulates Expression of CsNPR1 and CSPR1 Genes}

To characterize the expression patterns of CSNPR1 and CSPR1 genes, their response to various inductions were investigated in Cymbidium protoplasts. As shown in Figure 4, protoplasts were efficiently isolated from Cymbidium flower petals. The maximum yield and viability reached to approximately $3.3 \times 10^{7} / \mathrm{g}$ (fresh weight) and $92.3 \%$, respectively. Following protoplast treatments with various phytohormones and stresses, the relative expression levels of CSNPR1 and CSPR1 genes were measured by qRT-PCR.

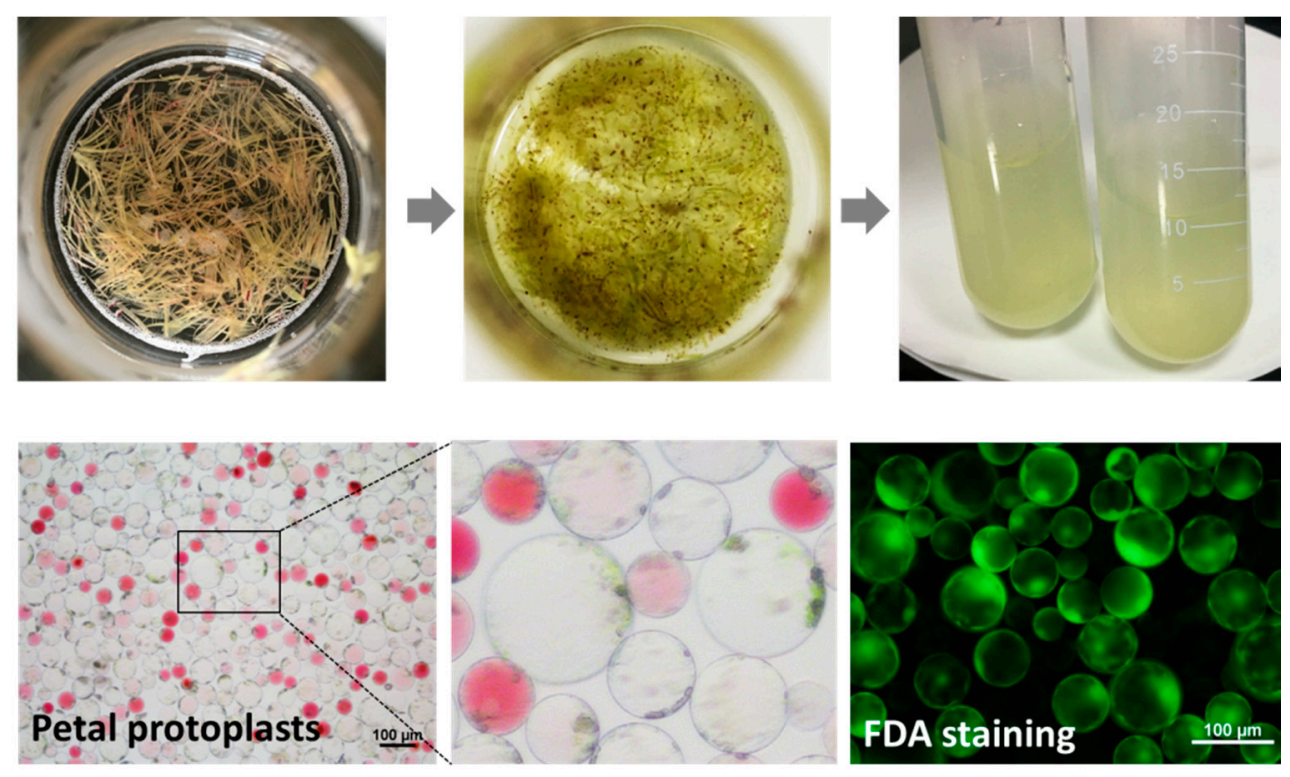

Figure 4. Protoplast isolation from the flower petals of Cymbidium orchids.

Protoplast treatments were simultaneously carried out, which is more reliable, repeatable and precise than using plants. With the addition of $100-\mu \mathrm{M} \mathrm{SA}$, CSNPR1 and CsPR1 genes exhibited similar inducible expression patterns, and their expression levels were greatly increased at the early stage $(6 \mathrm{hpt})$, and decreased gradually as time passed, when compared with controls at each timepoint (6, 12, and $24 \mathrm{hpt}$ ) (Figure 5A). Moreover, CsNPR1-2 showed greater fold changes (almost 20-40 folds) compared with other genes, which showed almost equal fold changes ( 3 to 4 folds). Meanwhile, the protoplast treated with $200-\mu \mathrm{M}$ Abscisic acid (ABA) was conducted (Figure 5A). Different from their responses to SA, only CsNPR1-3 was significantly up-regulated by ABA, while CsNPR1-1 and CsNPR1-2 showed no significant difference compared to the control at all three timepoints. Interestingly, CsPR1-1 and CsPR1-2 were also up-regulated by ABA at 6 and/or $12 \mathrm{hpt}$. Cymbidium protoplasts were also treated with hydrogen dioxide peroxide $\left(\mathrm{H}_{2} \mathrm{O}_{2}\right)$ and ascorbic acid (AsA), respectively. ASA is a water-soluble anti-oxidant molecule which acts as a primary substrate in the cyclic pathway of enzymatic detoxification of $\mathrm{H}_{2} \mathrm{O}_{2}$ [31]. The expressions of CsNPR1 and CsPR1 genes were significantly up-regulated in the presence of $\mathrm{H}_{2} \mathrm{O}_{2}$, but were remarkably inhibited with the added AsA when compared with controls at each timepoint (Figure 5B). Additionally, the protoplasts were also treated with $200-\mathrm{mM} \mathrm{NaCl}$ salinity stress. It was found that the expression levels of CsNPR1-1 and CsNPR1-3 were significantly up-regulated, while those of CSNPR1-2 showed few differences between the experimental and control groups (Figure 5C). The expressions of CsPR1 genes were only significantly up-regulated at $6 \mathrm{hpt}$ by salinity stress. Taken together, SA and ROS, but not ABA or salinity stresses, greatly triggered the expression of CSNPR1 and CsPR1 genes, and CsNPR1-2 was most responsive. 

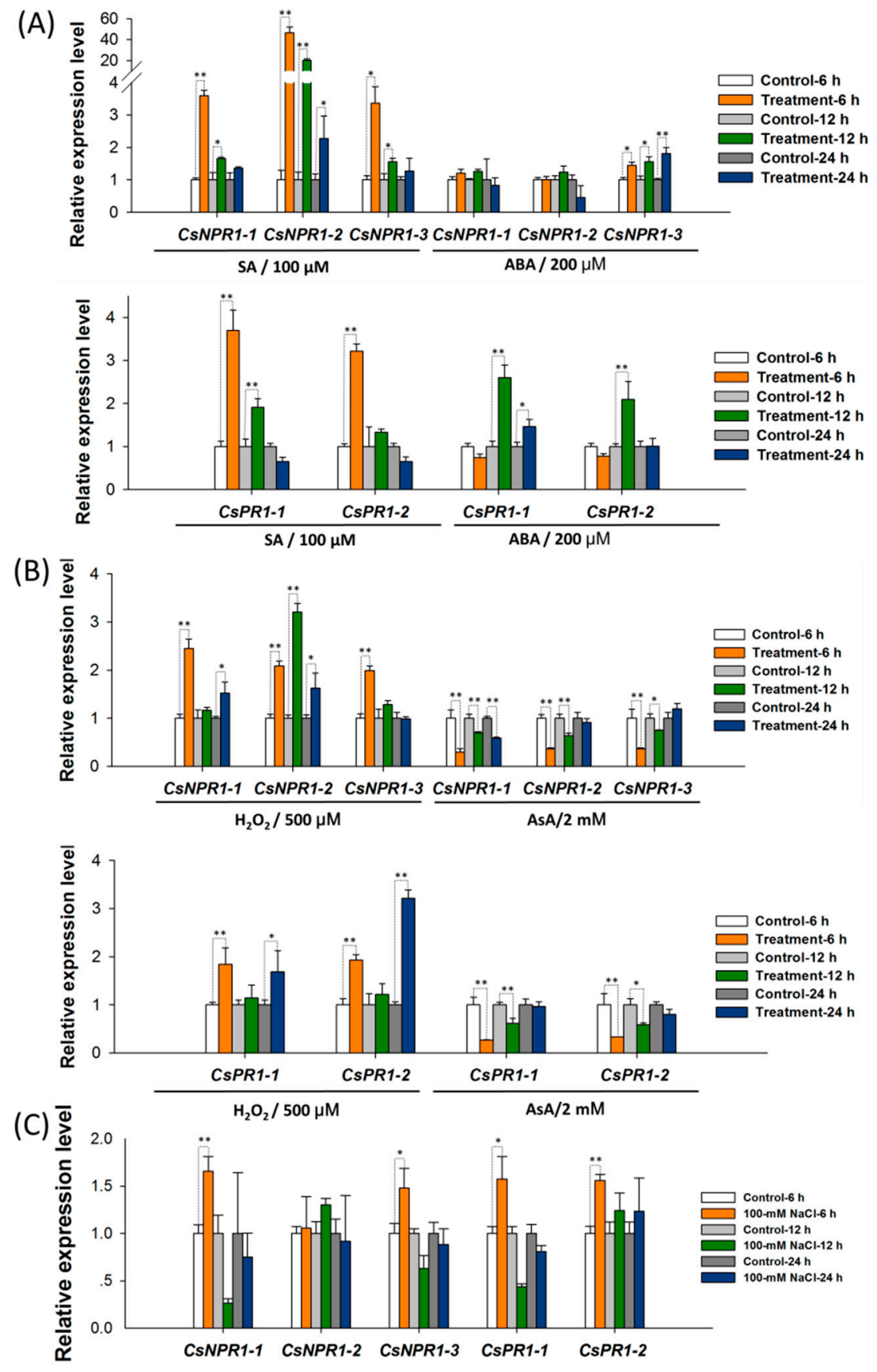

Figure 5. Expression analysis of $C s N P R 1$ and $C s P R 1$ genes in response to $S A, A B A, \mathrm{H}_{2} \mathrm{O}_{2}, A s A$ and salinity stress induction by qRT-PCR. Cymbidium protoplasts were treated with (A) SA and ABA, (B) $\mathrm{H}_{2} \mathrm{O}_{2}$ and AsA, as well as (C) abiotic stresses ( $\mathrm{NaCl}$, sodium chloride for salinity stress), and the relative expression levels of CsNPR1 and CsPR1 genes were measured by qRT-PCR. Y-axes indicate the relative expression levels; significant difference was assessed by Mann-Whitney U-test and indicated by asterisks; single asterisk $\left({ }^{*}\right)$ represents $p \leq 0.05$, double asterisk $\left({ }^{* *}\right)$ represents $p \leq 0.01$; Data are expressed as the mean of three biological replicates, with error bars indicating the SD.

\subsection{CsNPR1-2-Mediated Singling Pathway Confers the Response of Cymbidium orchids Against CymMV Infection}

To explore the expression patterns of the defense-related genes CSNPR1 and CsPR 1 in response to virus infection, the in vitro transcripts of entire CymMV-RNA and blank control (equal volumes of water) were transfected into Cymbidium protoplasts. Fluorescein diacetate (FDA) staining was used to 
determine protoplast viability at each timepoint. It was shown that most protoplasts remained viable after transfection (Figure 6A). The replication of CymMV in transfected protoplasts was detected by double-antibody sandwich-enzyme linked immunosorbent assay (DAS-ELISA) and RT-PCR. After $24 \mathrm{~h}$ of cultivation, CymMV replication was detectable in the protoplasts. The target-fragments of the CymMV-coat protein (CymMV-CP) coding sequence were amplified from transfected protoplasts at $24 \mathrm{hpt}$, while no product was amplified from the negative control sample (Figure 6B). Additionally, yellow coloration was observed in the DAS-ELISA wells representing CymMV infection of transfected protoplasts, and the $\mathrm{OD}_{405 \mathrm{~nm}}$ values exceeded three times that of the negative-control wells (Figure 6C). All these results indicated CymMV infection in the transfected Cymbidium protoplasts.

(A)

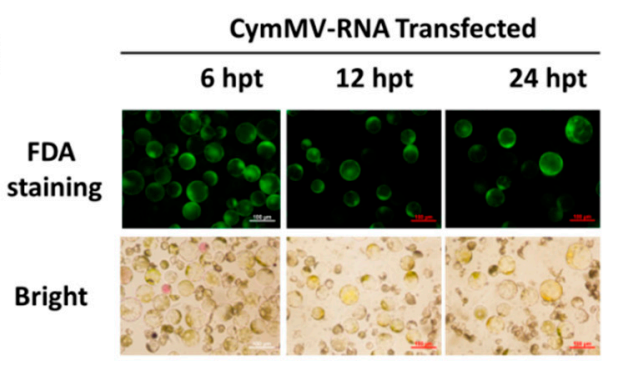

(B)

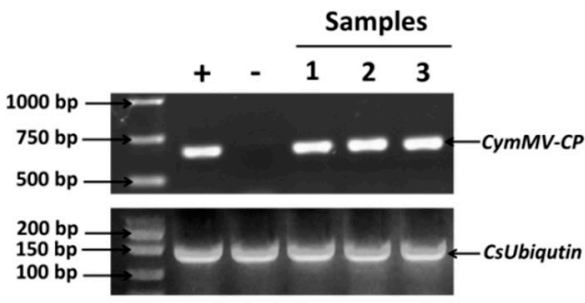

(D)
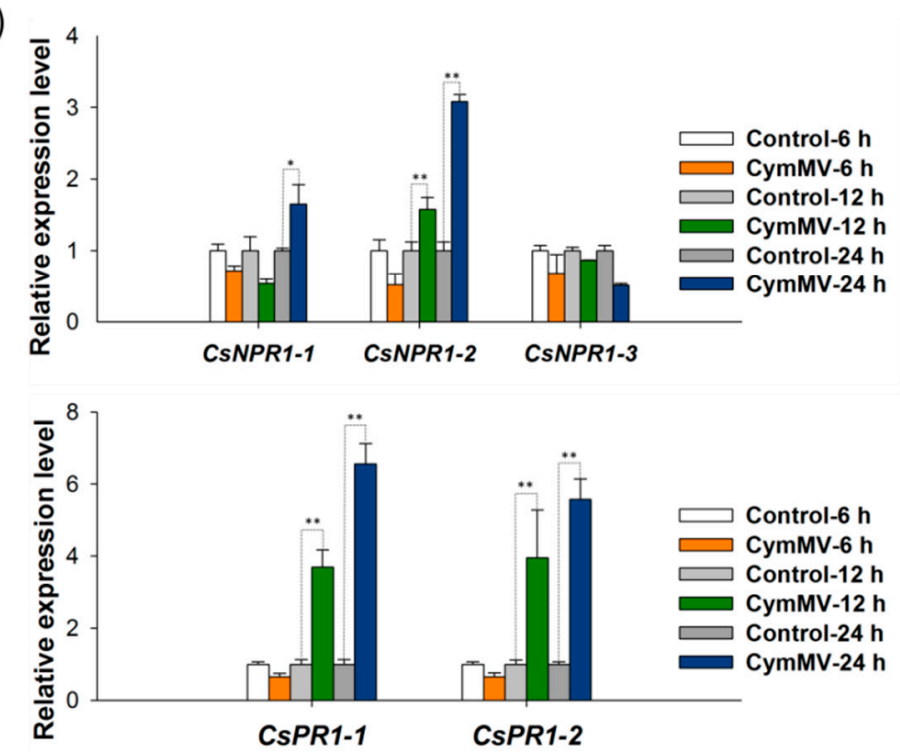

(C)
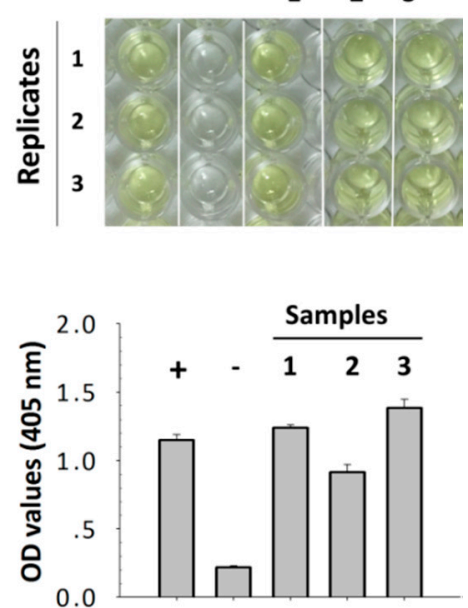

Figure 6. Expression analyses of $C s N P R 1$ and $C s P R 1$ genes in response to CymMV infection by qRT-PCR. (A) Cymbidium protoplasts were transfected with the in vitro transcripts of entire CymMV-RNA, and the viability of transfected protoplasts were examined by FDA staining; (B) the replication of CymMV in Cymbidium protoplasts were confirmed by RT-PCR with three replicates; (C) the replication of CymMV in Cymbidium protoplasts was confirmed by DAS-ELISA with three replicates; (D) the relative expression levels of CsNPR1 and CsPR1 genes in transfected protoplasts were measured by qRT-PCR; $\mathrm{Y}$-axes indicate the relative expression levels; significant difference was assessed by Mann-Whitney U-test and indicated by asterisks; single asterisk $\left(^{*}\right)$ represents $p \leq 0.05$, double asterisk $\left(^{* *}\right.$ ) represents $p \leq 0.01$; data are expressed as the mean of three biological replicates, with error bars indicating the SD. 
Subsequently, the expression patterns of CsNPR1 and CsPR1 genes in response to CymMV infection in Cymbidium protoplasts were examined at 6,12 and $24 \mathrm{hpt}$. As shown in Figure 6D, the expression of CsNPR1-2 was significantly up-regulated at 12 and 24 hpt compared with blank control, while that of CsNPR1-1 was slightly up-regulated and CsNPR1-3 was down-regulated at $24 \mathrm{hpt}$, respectively. Meanwhile, both CsPR1-1 and CsPR1-2 were greatly up-regulated by 4-6-fold from 12 to 24 hpt. Therefore, CsNPR1-2, rather than CsNPR1-1 and CsNPR1-3, conferred the orchid-immunity, and the NPR1-2-mediated singling pathway was involved in the Cymbidium response against CymMV infection.

\subsection{Nuclear Translocation of CSNPR1-2 in the Presence of SA}

To characterize the CsNPR1 and CsPR1 homologous proteins, they were transiently expressed in Cymbidium protoplasts for protein subcellular localization. Recombinant vectors expressing fusion proteins CsNPR1-1::GFP, CsNPR1-2::GFP CsNPR1-3::GFP, CsPR1-1::GFP and CsPR1-2::GFP, and an empty vector only expressing green fluorescent protein (GFP), were transformed into Cymbidium protoplasts (Figure 7A). Strong green fluorescence was observed in most protoplasts at 16-24 hpt, and a maximum transfection efficiency greater than $80 \%$ was achieved according to the ratio of protoplasts with fluorescence. Fusion proteins CsNPR1-2::GFP and CsNPR1-3::GFP were distributed throughout the entire cell, which was similar to that of the vector control, while CsNPR1-1::GFP, CsPR1-1::GFP and CsPR1-2::GFP were mainly expressed at the nucleus and plasma membrane (Figure 7B). In addition, the fusion protein CsNPR1-2::GFP accumulated in the nucleus in the present of $100 \mu \mathrm{M}$ SA (Figure 7B). However, adding SA did not change the subcellular localizations of fusion proteins CsPR1-1::GFP and CsPR1-2::GFP. These results indicated that the presence of SA induced the nuclear translocation of CsNPR1-2 protein.

(A)

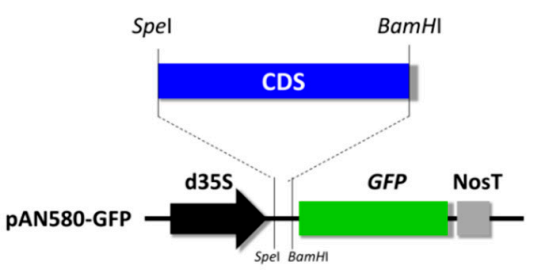

(B)
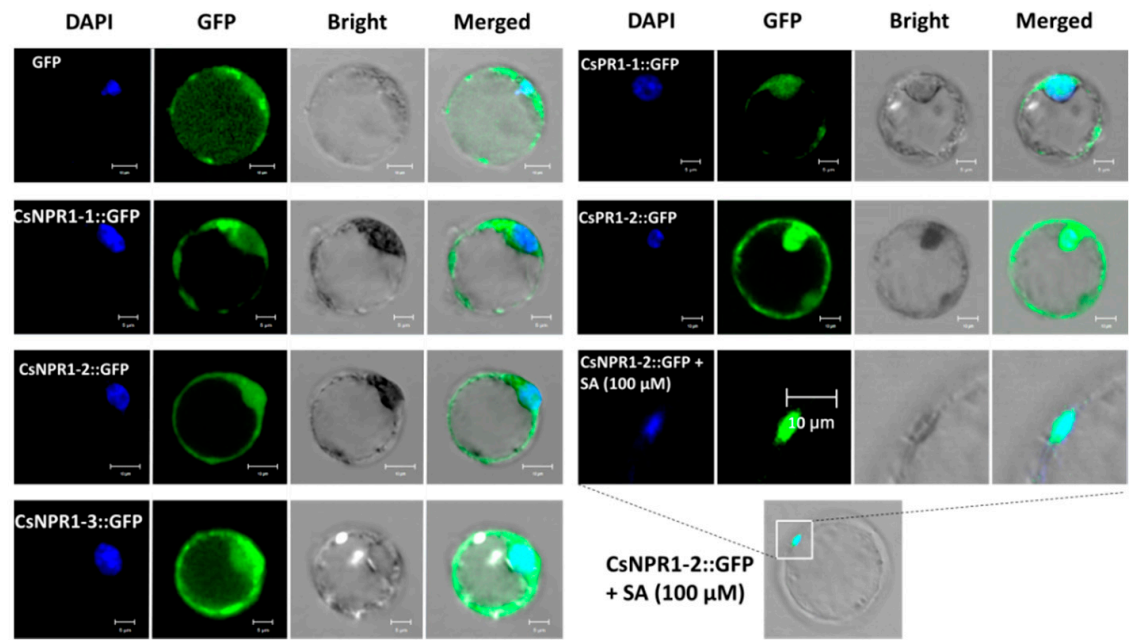

Figure 7. Transient expression of CSNPR1-2 in Cymbidium protoplasts. (A) Vectors used for transient expression were obtained by cloning the full-length CDSs into the vector PAN580-GFP; (B) Plasmid DNA expressing GFP and fusion protein were transfected into Cymbidium protoplasts, and the fluorescence was detected under an LSM 710 confocal laser microscope with a blue excitation block at 12-18 h post-transfection; In the presence of SA $(100 \mu \mathrm{M})$, fusion protein CsNPR1-2::GFP was co-localized with the DAPI signal, indicating the nuclear localization of CsNPR1-2 protein. 


\subsection{CSNPR1-2 Positively Regulate the Expression of CsPR1 Genes}

To profile the NPR1-mediated singling pathway in Cymbidium orchids, the regulation of the strong candidate CsNPR1-2 protein on expression of CsPR1 genes was investigated. Protoplasts transiently expressing fusion protein CsNPR1-2::GFP were collected at 6, 12 and $24 \mathrm{hpt}$, and expressions of CsPR1-1 and CsPR1-2 genes were examined using qRT-PCR. Fusion protein CsNPR1-2::GFP was successfully expressed with bright green fluorescence in most Cymbidium protoplasts at $24 \mathrm{hpt}$. The expression levels of CsNPR1-2 reached 200-2500 fold during 6-12 hpt (Figure 8). Meanwhile, the expressions of CSPR1 genes were greatly up-regulated throughout 6-24 hpt, but excess CsNPR1-2 accumulation led to the decreased expression of CsPR1 genes. Despite CsPR1-1 and CsPR1-2 showing similar expression patterns, the relative expression level of CsPR1-2 was almost 10 -times that of CsPR1-1. These results indicated that transient expression of CSNPR1-2 protein greatly enhanced the expression of CsPR1 genes in Cymbidium orchids.
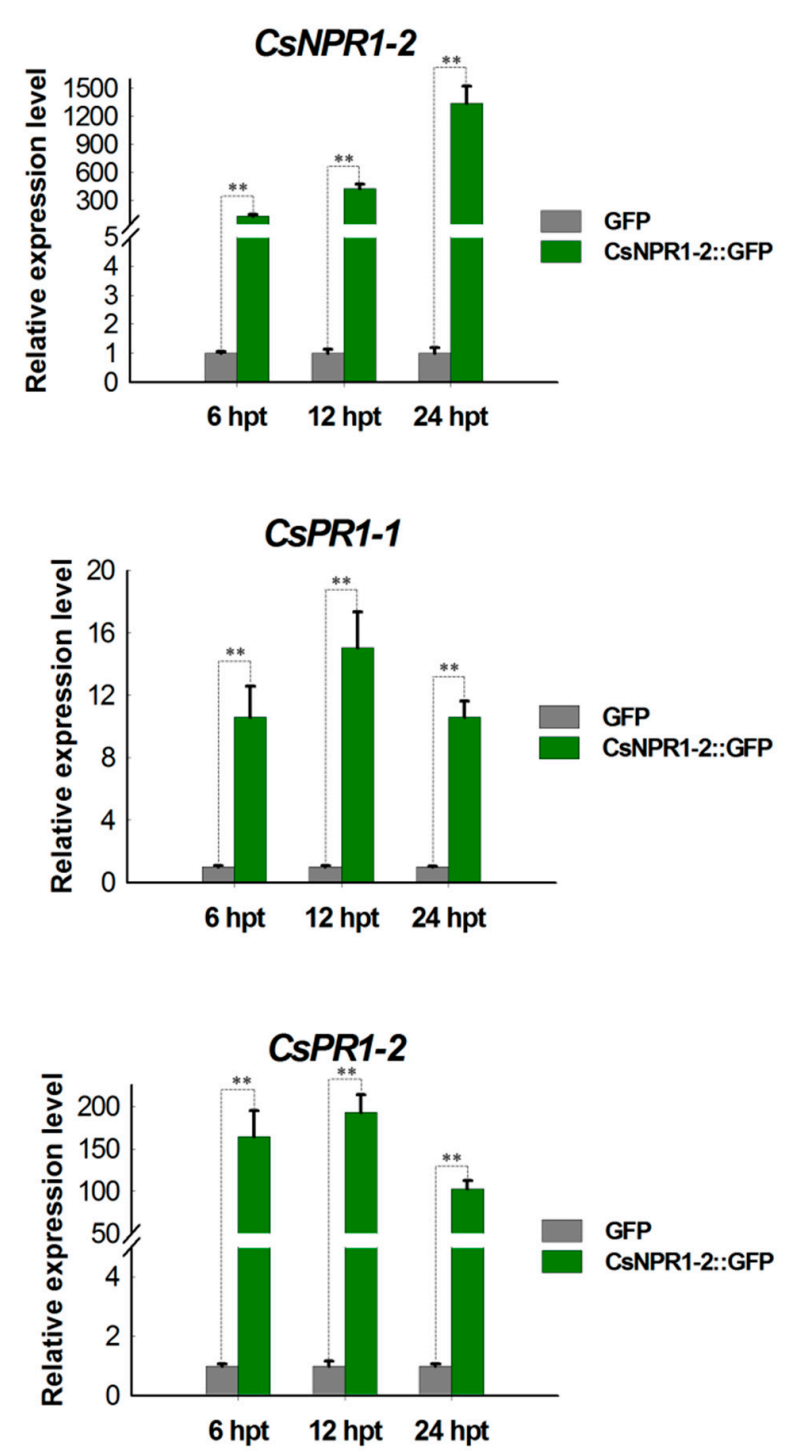

Figure 8. Regulation analysis of CSNPR1-2 protein on expression of CsPR1 genes by qRT-PCR. Protoplasts transiently expressing fusion protein CsNPR1-2::GFP were collected at 6, 12 and $24 \mathrm{hpt}$, and the expression of CsPR1-1 and CsPR1-1 genes were examined by qRT-PCR. Y-axes indicate the relative expression levels; significant difference was assessed by Mann-Whitney U-test and indicated by asterisks; single asterisk $\left(^{*}\right)$ represents $p \leq 0.05$, double asterisk $\left(^{* *}\right)$ represents $p \leq 0.01$; data are expressed as the mean of three biological replicates, with error bars indicating the SD. 


\section{Discussion}

Plant pathogens seriously affect the global production of crops and horticultural species [32,33]. Reasonable disease management approaches are eco-friendly and desirable to limit production inputs and provide economic benefits to farmers [33]. Plant defense/immunity mechanisms against various pathogens have been studied extensively in model plants and main crops. However, insufficient genomic information and laggard biotechnology greatly limit the discovery of $R$-genes in horticultural species. The identification and application of key homologs has been proven an efficient method to generate disease-resistant transgenic plants [34-39]. Heterologous expression of AtNPR1 in horticultural crops such as tomato [35], carrot [40] and citrus [37] shows the potential to generate transgenic plants with increased broad-spectrum disease and pest resistance. Herein, we identified three NPR1-like and two PR1-like homologs from Chinese Cymbidium orchids, which are splendid ornamental plants worldwide. A detailed characterization and utilization of these plant defense-related homologs would facilitate disease-resistance breeding in Orchidaceae and other plant species.

Previously, full-length transcripts of PhaNPR1 and PhaPR1 were obtained with the primers designed from the conserved domain sequences and the rapid amplification of cDNA ends [25]. However, the reported NPR1-like families in other plant species are comprised of several members, for instance, six NPR1-like genes (AtNPR2, AtNPR3, AtNPR4, AtNPR5/AtBOP1 and AtNPR6/AtBOP2) have been described in Arabidopsis [41]. Hence, we inferred that there should be more members of the NPR1-like family in the orchid genome with potentially sub-functional differentiation. In this study, a genome-wide identification of NPR1 and PR1 homologs was carried out against an unpublished Cymbidium orchid genome dataset. A total of three CSNPR1-like and two CsPR1-like genes were identified from C. sinense (Figure 1). For these putative Cymbidium NPR1-like proteins, CsNPR1-1 showed the closest homology with ZmNPR1 from Zea mays (sharing 81.98\% identity), but CsPR1-2 with PhaNPR1 showed the closest homology with the Phalaenopsis orchid (64.14\% identity) (Figure 2). As one of the most evolved families of monocot plants [1], the genomic organization of CsNPR1-like and CSPR1-like families in orchids might be more complex than in other plant species. The NPR1 plays a key role in multiple signaling pathways in plant immunity [12], as well as in plant development [42] and abiotic-stress tolerance [13-15]. Moreover, AtNPR1 and AtNPR4 exhibit opposite roles in early defense gene expression in response to SA [43]. In the present study, CsNPR1-2 showed different expression patterns to CSNPR1-1/3 (Figures 4-6), indicating that they probably have different roles in the NPR1-dependent singling pathway.

The responses of plants to pathogen infection, and other biological and abiotic stresses, involve changes in ROS and hormone levels [44-47]. This led us to investigate the involvements of CsNPR1 and $C_{s} P R 1$ homologs in response to various inductions, including by $\mathrm{SA}, \mathrm{H}_{2} \mathrm{O}_{2}, \mathrm{ABA}$, salinity $(\mathrm{NaCl})$ stress and CymMV infection. Although CsNPR1 and CsPR1 genes maintained a low expression level in healthy plants (Figure 3B), they were significantly up-regulated by the inductions. Briefly, the presence of SA significantly up-regulated the expression of CsNPR1 genes at $6 \mathrm{hpt}$ (Figure 5A), and caused the nuclear translocation of the CsNPR1-2 protein (Figure 7B). These results indicated that CsNPR1-2 was involved in the response and transduction of SA signals in Cymbidium orchids (Figure 8). Though plant NPR1 regulates the expression of PR1-like genes via the interaction with basic leucine zipper protein transcription factors [48-51], exogenous SA and the transient expression of CSNPR1-2 enhanced the expression of CsPR1-1 and CsPR1-2 (Figures 5A and 8). Moreover, the expression levels of CsPR1 genes upregulated by CSNPR1-2 overexpression were much higher than those upregulated by SA, indicating that SA triggered the expression of CSPR1 genes through the promotion of CSNPR1-2 expression. In conjunction with SA and nitric oxide, ROS primarily function as signal transduction molecules in crosstalk among different pathways [52,53]. Herein, the expressions of CSNPR1-2, CsPR1-1 and CsPR1-2 were greatly up-regulated by $\mathrm{H}_{2} \mathrm{O}_{2}$ induction and CymMV infection (Figures 5 and 6). Plant viral infection usually results in an ROS burst and hypersensitive necrosis [54,55], but this requires further verification with regard to the CymMV infection of orchid plants. It was inferred that the 
defense response of Cymbidium orchids against CymMV infection probably started with the ROS burst and accumulated SA, which in turn activated the CsNPR1-2 expression and CsPR1 genes (Figure 9).

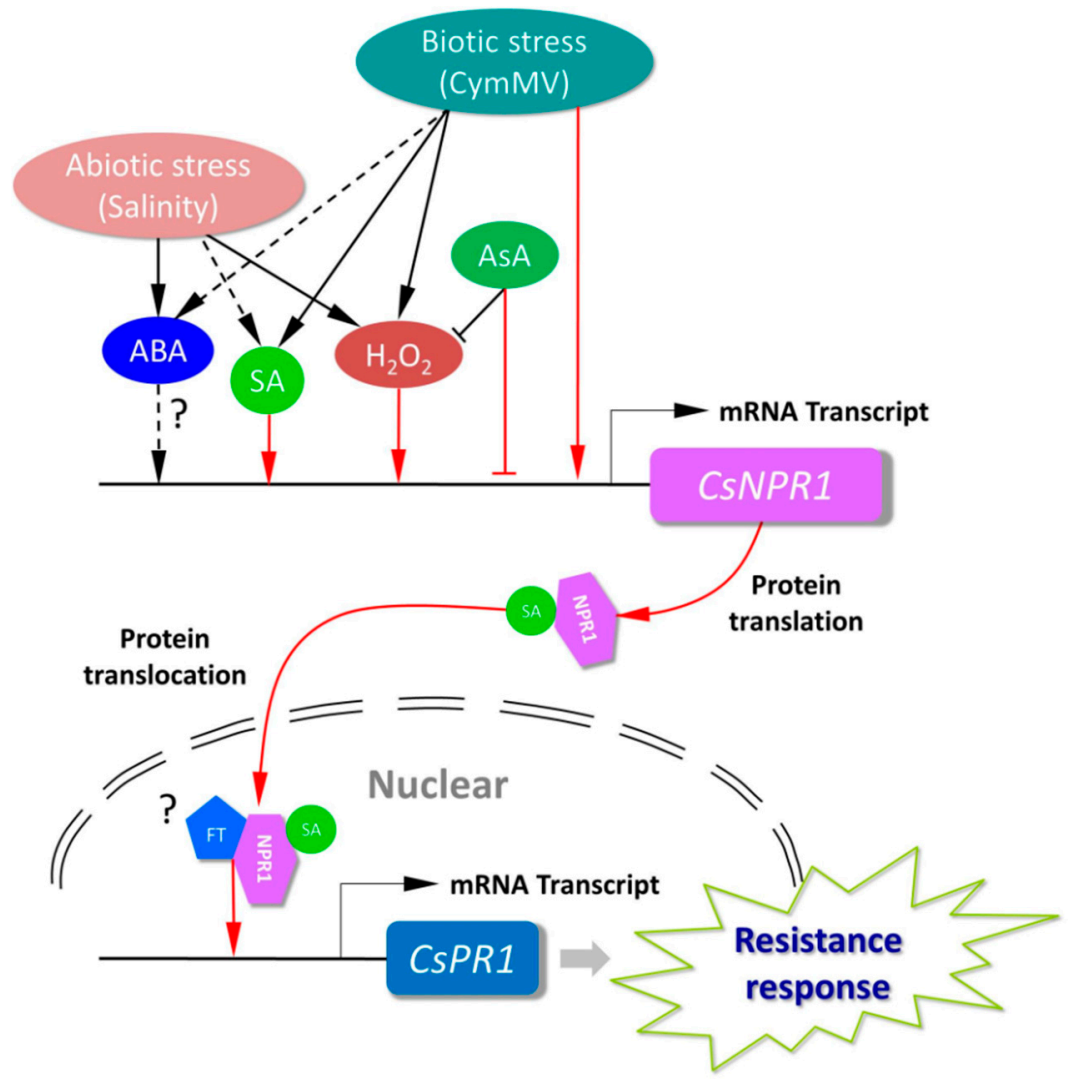

Figure 9. NPR1-mediated signaling pathway in Cymbidium orchid. Stress and phytohormones are represented by ellipses; genes are represented by rectangles; and lines before rectangles represent the transcriptional regulatory regions. Lines with an arrow represent the promotion of mRNA transcript, and those with a perpendicular bar represent repression. Red lines indicate the regulation or transportation demonstrated in this study.

Traditionally, plant viruses can be easily mechanically inoculated into dicot hosts, such as soybean, tobacco and cucumber [56]. However, it is very difficult to mechanically inoculate the virus into the leathery leaves of orchids and some other monocot plants for plant-virus interaction study. Hence, in-vitro-transcribed entire viral genomic RNA or viral infectious clone vectors were transformed into protoplasts, which enables virus replication [57-59] and virus-plant interaction studies [60-62]. In this study, Cymbidium protoplasts were transfected with in-vitro-transcripted entire CymMV-RNA, and CymMV were detectable in the transfected protoplast at 24 hpt (Figure 6B,C). The viral replication in protoplasts means that the virus utilizes the transcription and translation systems of plant cells [63]. The plant-virus interaction triggered the expression of CsNPR1 and CsPR1 genes (Figure 6D), indicating that our protoplast-based viral-RNA transfection method can be successfully used for orchid-virus research.

\section{Materials and Methods}

\subsection{Plant Materials}

Healthy virus-free Cymbidium sinense plants were used. These orchid plants were obtained from the orchid breeding base of Environmental Horticulture Research Institute, Guangdong Academy 
of Agricultural Sciences, China, and maintained in plastic pots $(20 \times 20 \mathrm{~cm})$ in greenhouses with a favorable environment for growing as previously described [64].

\subsection{Genome-Wide Identification of NPR1-like and PR1-like Genes in Cymbidium Sinense}

The sequences of PhaNPR1 in Phalaenopsis aphrodite (GenBank accession number: JN630802.1) and OsNPR1 in rice (DQ450947.1) (Table S1), as well as PhaPR1 in P. aphrodite (JX137044.1) and OsPR1 in rice (AF306651.1) were retrieved from the National Center for Biotechnology Information (NCBI) GenBank (https://www.ncbi.nlm.nih.gov) database (Table S2). A local protein database of Cymbidium sinense (unpublished) was established for the basic local alignment search (BLAST, ftp://ftp.ncbi.nlm. nih.gov/blast/executables/blast+/LATEST/). These deduced protein homolog sequences were used as queries to search for NPR1-like and PR1-like proteins in the protein database of Cymbidium sinense (E-value $<1 \times 10^{-5}$ ). Candidate sequences were retrieved and verified for conserved domains using the Pfam database (https://pfam.xfam.org/) and InterPro database (http://www.ebi.ac.uk/interpro/), and candidate proteins without conserved domains were removed. Finally, the genes encoding the putative NPR1-like and PR1-like proteins were identified from the unpublished Cymbidium sinense genome. Exon-intron structures of these identified genes were predicted with the GENSCAN software (http://genes.mit.edu/GENSCAN.html). The CDSs of CsPR1-like and CsNPR1-like homologs were identified according to our previous De novo transcriptome assembly data [65].

\subsection{Sequence and Phylogenetic Analysis}

Total RNA was extracted from the young leaves of Cymbidium sinense with a RNA Simple Total RNA Kit (Tiangen, Beijing, China). The DNA-free RNA was used for first-strand cDNA synthesis using Oligo (dT) primers and a PrimeScript ${ }^{\mathrm{TM}}$ U1st strand cDNA Synthesis Kit (Takara, Dalian, China) following the manufacturer's instructions. Gene-specific primers were designed according to the CDSs of CsPR1-like and CsNPR1-like suing Primer Premier 5.0 software (Premier, Palo Alto, CA, USA) (Table S3). Subsequently, the fragments for each gene were amplified from the cDNA using PrimerSTAR Max DNA Polymerase (Takara, Dalian, China). Purified products were cloned into the pMD18-T vector (Takara, Dalian, China) and sequenced. The obtained CDSs of CsNPR1-like and CsPR1-like genes were analyzed for ORFs using GENESCAN software. The domains and architectures of putative proteins were predicted using online software SMART (http://smart.embl-heidelberg.de) and InterProScan (http://www.ebi.ac.uk/InterProScan).

Phylogenetic analysis and sequence alignments were conducted with the full-length deduced amino acid sequences of NPR1-like and PR1-like proteins (Tables S1 and S2). The phylogenetic trees were generated using the MEGA 5.10 software with the neighbour-joining method applying 1000 replicates [66]. According to the results of phylogenetic analysis, homologs in other species having close phylogenetic relationships were aligned and analyzed for protein identities using Geneious Prime v. 2019.0.3 (BioMatters, Ltd., Auckland, New Zealand).

\subsection{Tissues Collection and Protoplast Isolation}

Various tissues including root tip, stem (protocorm), leaf, flower petal and immature pod were collected from healthy Cymbidium sinense plants. Total RNA was extracted, and DNA-free RNA was reverse-transcribed as mentioned above. The expression levels of CsNPR1-like and CsPR1-like genes in various tissues/organs were examined by quantitative real-time polymerase chain reaction (qRT-PCR).

Moreover, the fully expanded flower petals were also collected for protoplast isolation. The protoplast isolation was conducted following the past protocols $[67,68]$. Generally, petals were cut into $0.5 \sim 1.0 \mathrm{~mm}$ strips and transferred into the freshly prepared enzyme-solution $(1.0 \%$ (weight/volume, $w / v)$ Cellulase R10, 0.5\% (w/v), Macerozyme R10, 500-mM D-mannitol, 20-mM KCl, and 20-mM MES $\left.(\mathrm{pH}=5.7), 10-\mathrm{mM} \mathrm{CaCl}_{2}, 0.1 \%(w / v) \mathrm{BSA}\right)$. The released protoplasts were harvested after incubation at $28^{\circ} \mathrm{C}$ in the darkness with rotations of $30 \mathrm{rpm}$ for $5-6 \mathrm{~h}$. The purified protoplasts were adjusted to a suitable density with W5 solution (154 mM NaCl, $125 \mathrm{mM} \mathrm{CaCl}_{2}, 5 \mathrm{mM} \mathrm{KCl}$ and $2 \mathrm{mM} \mathrm{MES}$, pH 5.7). 


\subsection{Protoplast Measurements and Treatments}

Protoplasts were counted and photographed with a hemocytometer under a Leica DM2500 microscope (Leica, Wetzlar, Germany). FDA staining was used to determine protoplast viability [69], under a LSM 710 confocal laser microscope (Carl Zeiss, Inc., Jena, Germany). The different treatments of protoplasts were carried out in W5 solution supplemented with $100 \mu \mathrm{M} \mathrm{SA}, 500 \mu \mathrm{M} \mathrm{H}_{2} \mathrm{O}_{2}, 2 \mathrm{mM}$ AsA, $200 \mu \mathrm{M} \mathrm{ABA}$ and $100 \mathrm{mM} \mathrm{NaCl}$. The optimum concentrations of treatments were determined according to those for other plants, such as Arabidopsis [53], rice [70], Phalaenopsis [70] and soybean [71]. Approximately $10^{6}$ protoplasts in $1 \mathrm{~mL} \mathrm{W5}$ solution were used for each treatment. W5 solution was supplemented with water as the control treatment at each timepoint. Protoplasts were cultivated in 6-well plates in a growth chamber at $23^{\circ} \mathrm{C}$ for $6-24 \mathrm{~h}$ in the darkness.

\subsection{In Vitro Transcription of CymMV-RNA and Vector Preparation}

The viral RNA was generated from plasmid p18Cy13, a biologically active cDNA clone of CymMV encompassing the entire viral RNA of CymMV and T7 RNA polymerase promoter fused to the 5' extreme of the viral cDNA [72]. Plasmid p18Cy13T7 (gift from Prof. Sek-Man Wong, National University of Singapore) was linearized with $S m a \mathrm{I}$, and the digested DNA was purified and transcribed using the mMESSAGE mMACHINE ${ }^{\mathrm{TM}}$ T7 Ultra kit (Ambion mMessage mMachine, Austin, TX, USA) following the manufacturer's instructions. In vitro transcripts $(15 \mu \mathrm{g})$ were then transfected into Cymbidium protoplasts.

The vectors used for protoplast-based transient expression were obtained by inserting the CDSs of these genes into the vector PAN580-GFP. The gene-specific primers with overlapping homologous ends were designed using Primer Premier 5.0 software (Premier, Palo Alto, CA, USA) according to the full-length CDSs of CsNPR1 and CsPR1 genes (Table S3). Subsequently, the fragments for each gene were amplified and purified, and full-length CDS without a termination codon were cloned into the PAN580-GFP vector by recombination using the Seamless Assembly Cloning Kit (CloneSmarter, Houston, TX, USA) following the manufacturer's instructions. Recombined vectors were transformed into Escherichia coli DH5 $\alpha$-competent cells (TianGen, Beijing, China) according to the manufacturer's instructions and confirmed by sequencing. Following mass replication of the bacterium, plasmid DNA was extracted by Endo-Free Plasmid Maxi Kit (Omega Bio-tek, Norcross, GA, USA). The concentrated plasmid DNA $(2.0 \mu \mathrm{g} / \mu \mathrm{L})$ was prepared for protoplast transfection.

\subsection{PEG-Mediated Protoplast Transfection}

Protoplast transfection was carried out using the PEG-mediated protocol with minor modifications [67]. Briefly, an equal volume of freshly prepared PEG solution $(40 \%(w / v)$ PEG 4000, 0.2 M mannitol and 0.1 $\mathrm{M} \mathrm{CaCl}_{2}$ ) was gently mixed with pre-assembled in-vitro-transcripted CymMV-RNA or plasmid DNA in MMG solution (15 $\mathrm{mM} \mathrm{MgCl}_{2}, 0.4 \mathrm{M}$ mannitol and $4 \mathrm{mM}$ MES $(\mathrm{PH}=5.7))$. Transfected protoplasts were incubated at $23^{\circ} \mathrm{C}$ for $6-24 \mathrm{~h}$ in the darkness. Transfection efficiency was measured according to the expression of the GFP reporter of the transient expression vector pAN580-GFP. The GFP fluorescence was observed and 3-5 images were taken in random distribution under a LSM 710 confocal laser scanning microscope. For protein subcellular localization, the transfected protoplasts were stained with $50 \mu \mathrm{g} / \mathrm{mL} \mathrm{4} 4^{\prime}-6^{\prime}$-diamidino-2-phenylindole (DAPI) to detect cell nucleus [73]. DAPI signals were excited with Blue Diode Laser under a LSM 710 confocal laser microscope.

\subsection{RT-PCR and $q R T-P C R$}

The replication of CymMV in transfected Cymbidium protoplasts was detected by RT-PCR. Protoplasts transfected with CymMV-RNA were harvested at 12, 24 and $36 \mathrm{~h}$ post-transfection (hpt). The first-strand cDNA was obtained from the total RNA of transfected protoplasts and virus-infected $N$. benthamiana leaves. Gene-specific primers were designed according to the CDS of CymMV-coat 
protein (CymMV-CP) using Primer Premier 5.0 software (Premier, Palo Alto, CA, USA), and Cs Ubiquitin in Cymbidium (referred to as CsUBQ, Gene bank accession No: AY907703) was used as an internal reference control (Table S3). RT-PCR was performed in a $20-\mu \mathrm{L}$ reaction volume comprising $2.0 \mu \mathrm{L}$ (approximately $50 \mathrm{ng}$ ) of first-strand cDNA, $0.8 \mu \mathrm{L}$ of each forward and reverse primer $(10.0 \mu \mathrm{M}), 10.0$ $\mu \mathrm{L}$ of $2 \times$ Taq Master Mix (Vazyme Biotech Co., Ltd., Nanjing, China) and $6.4 \mu \mathrm{L}$ of sterile distilled $\mathrm{H}_{2} \mathrm{O}$. All reactions were performed in $200 \mu \mathrm{L}$ centrifuge tubes using a Bio-Rad T100 ${ }^{\mathrm{TM}}$ Thermal Cycler (Bio-Rad, Hercules, CA, USA). The following PCR conditions were used: $95^{\circ} \mathrm{C}$ for $5 \mathrm{~min}$, followed by 30 cycles at $95^{\circ} \mathrm{C}$ for $15 \mathrm{~s}, 60^{\circ} \mathrm{C}$ for $30 \mathrm{~s}$ and $72{ }^{\circ} \mathrm{C}$ for $30 \mathrm{~s}$, and then at $68^{\circ} \mathrm{C}$ for $5 \mathrm{~min}$. Finally, PCR products were evaluated using agarose gel $(2 \%)$ electrophoresis.

The expression levels of CSNPR1 and CsPR1 genes were measured by qRT-PCR. Gene-specific primers for qRT-PCR were designed according to CDSs of CsNPR1 and CsPR1 genes using the Primer Premier 5.0 software (Premier, Palo Alto, CA, USA) (Table S3). The gene CsUBQ was used as an internal reference control to normalize the total amount of cDNA in each reaction. PCR was conducted, and only primers that amplified a single product were selected for qRT-PCR. The qRT-PCR was performed in a $20-\mu \mathrm{L}$ reaction volume comprising $2.0 \mu \mathrm{L}$ (approximately $20 \mathrm{ng}$ ) of $5 \times$ diluted first-strand cDNA, $0.8 \mu \mathrm{L}$ of each primers $(10.0 \mu \mathrm{M}), 10.0 \mu \mathrm{L}$ of $2 \times$ SYBR Green I Master Mix (Takara, Dalian, China) and $6.4 \mu \mathrm{L}$ of sterile distilled $\mathrm{H}_{2} \mathrm{O}$. All reactions were performed in 96-well reaction plates using a Bio-Rad CFX-96 Real-time PCR System (Bio-Rad, Hercules, CA, USA) with three technical replicates. The following PCR conditions were used: $95^{\circ} \mathrm{C}$ for $5 \mathrm{~min}$, followed by 40 cycles at $95^{\circ} \mathrm{C}$ for $15 \mathrm{~s}$, $60{ }^{\circ} \mathrm{C}$ for $30 \mathrm{~s}$ and $72{ }^{\circ} \mathrm{C}$ for $30 \mathrm{~s}$, and then at $68^{\circ} \mathrm{C}$ for $5 \mathrm{~min}$. The expression of candidate genes was quantified using the relative quantification $\left(2^{-\Delta \Delta C T}\right)$ method [71]. Each sample was independently collected with three biological replicates.

\subsection{DAS-ELISA}

The presence of CymMV in transfected Cymbidium protoplasts was detected by DAS-ELISA using a DAS-ELISA kit (Agdia Inc., Elkhard, IN, USA) following the manufacturer's instructions. Transfected protoplasts (approximately $1 \times 10^{6}$ protoplasts) were harvested at $24 \mathrm{hpt}$ with three replicates. Leaves from $N$. benthamiana plants infected with CymMV served as positive control, while virus-free $N$. benthamiana leaves served as a negative control. Briefly, protoplasts were centrifuged at $100 \mathrm{~g}$ for $2 \mathrm{~min}$, and the supernatant was carefully removed. The protoplast pellets were homogenized using $350 \mu \mathrm{L}$ general extraction buffer, and then $100 \mu \mathrm{L}$ of the respective mixture was added into three repeat wells of a 96-well ELISA-plate. The plate was coated with $100 \mu \mathrm{L}$ coating antibody diluted in coating buffer $(1: 100, v / v)$ four hours before, and then washed with washing buffer for $4-6$ times. After incubation at $4{ }^{\circ} \mathrm{C}$ overnight, the wells were washed for 6-8 times using the washing buffer, followed by the addition of the detection antibody and alkaline phosphatase enzyme conjugate $(1: 100, v / v)$ solution, and incubated at $24{ }^{\circ} \mathrm{C}$ for $2 \mathrm{~h}$. The wells were washed 6-8 times using the washing buffer followed by adding $100 \mu \mathrm{L}$ substrate solution containing $1 \mathrm{mg} / \mathrm{mL}$ disodium 4-nitrophenyl phosphate salt. The plate was incubated at room temperature for 30-120 min. The presence of the virus was indicated by a yellow coloration in the respective wells upon visual observation. The absorbance values were measured at $405 \mathrm{~nm}\left(\mathrm{OD}_{405} \mathrm{~nm}\right.$ value) using a Bio-Rad iMark ${ }^{\mathrm{TM}}$ microplate absorbance reader (Bio-Rad Laboratories, Hercules, CA, USA). The presence of the virus was confirmed when the optical density $\left(\mathrm{OD}_{405 \mathrm{~nm}}\right)$ value was at least five times higher than that of buffer-control wells [74].

\subsection{Statistical analysis}

The statistical analysis was performed with SPSS Version 18.0 software (SPSS Inc., Chicago, IL, USA). All experiments were replicated three times. Data are presented as mean-standard error from three independent experiments. Significant differences among treatments were determined at $p \leq 0.05$ and $p \leq 0.01$ based on the least significant difference test by Mann-Whitney U-test. 


\section{Conclusions}

Based on a genome-widely identification, three CsNPR1-like (CsNPR1-1, CsNPR1-2 and CsNPR1-3) and two CsPR1-like (CsPR1-1 and CsPR1-2) genes were isolated from Cymbidium orchids. Proteins CsNPR1-1 and CsNPR1-2 were grouped closest to NPR1 homologs in Zea mays (sharing 81.98\% identity) and Phalaenopsis (64.14\% identity), while CsNPR1-3 was classified into a distinct group with the Calotropis procera NPR1 (70.68\% identity) and Oryza sativa NPR3 (57.72\% identity). Putative CsPR1-1 and CsPR1-2 proteins were highly conserved (99.40\% identity) and grouped closest to PR1 proteins in Phalaenopsis and other monocot species. Genes CsNPR1 and CsPR1 were highly expressed in stem/pseudobulb and/or flower, and they were greatly up-regulated by SA, ROS and CymMV infection, but not by ABA or salinity stress. Compared with CSNPR1-1 and CSNPR1-3, CsNPR1-2 showed greater fold changes, but CSPR1-1 and CSPR1-2 showed almost equal expression levels. In addition, the presence of SA led to the nuclear translocation of CsNPR1-2 protein, and the transient expression of CsNPR1-2 greatly enhanced expression of CsPR1 genes. All these results indicate that the NPR1-mediated signaling pathway in Cymbidium orchids is SA-dependent and can be triggered by ROS induction and CymMV infection. Therefore, the findings of this study can do a great deal to accelerate the healthy growth of orchids, one of the most loved aesthetic beauties the world over.

Supplementary Materials: Supplementary materials can be found at http://www.mdpi.com/1422-0067/21/6/1977/ s1.

Author Contributions: Conceptualization, G.Z., F.Y.; Investigation, R.R., Y.W., S.A., J.J., J.G., C.L.; Formal Analysis, R.R., Y.W.; Data Curation, J.J.; Writing-Original Draft, R.R.; Writing-Review and Editing, R.R., S.A., Y.W., G.Z., F.Y.; Supervision, R.R.; Project Administration, G.Z., F.Y.; Funding Acquisition, G.Z., F.Y. All authors have read and agreed to the published version of the manuscript.

Funding: This work was supported by grants from the National Key Technologies R \& D Program (2019YFD1001003, 2018YFD1000401), Chinese postdoctoral science foundation (2018M643033), R\&D plan in key areas of Guangdong Province (2018B020202001), Natural Science Foundation of Guangdong province (2017A030312004), Guangdong modern agricultural industrial technology system flower innovation team expert project (2019KJ121), Guangzhou scientific research project (201904020026,201707010307), Guangdong academy of agricultural sciences President fund 201721, 201834, 201804b), Discipline team Building projects of Guangdong Academy of Agricultural Sciences in the 13th Five-Year Period (201612TD).

Acknowledgments: Thanks to Sek-Man Wong at National University of Singapore for gifting the Plasmid p18Cy13T7 vector and paper revision.

Conflicts of Interest: The authors declare no conflict of interest.

$\begin{array}{ll}\text { Abbreviations } \\ \text { ABA } & \text { Abscisic acid } \\ \text { ANK } & \text { Ankyrin repeat } \\ \text { AsA } & \text { Ascorbic acid } \\ \text { BTB/POZ } & \text { Bric-a-brac/poxvirus and zinc finger } \\ \text { CDS } & \text { Coding sequence } \\ \text { CymMV } & \text { Cymbidium mosaic virus } \\ \text { DAS-ELISA } & \text { Double antibody sandwich-enzyme linked immunosorbent assay } \\ \text { FDA } & \text { Fluorescein diacetate } \\ \text { GFP } & \text { Green fluorescent protein } \\ \text { PR1 } & \text { Pathogenesis-associated 1 } \\ \text { qRT-PCR } & \text { Quantitative reverse transcription -polymerase chain reaction } \\ \text { ROS } & \text { Reactive oxygen species } \\ \text { SA } & \text { Salicylic acid } \\ \text { SAR } & \text { Systemic acquired resistance } \\ \text { SCP } & \text { Sterol carrier protein } \\ \text { SD } & \text { Standard deviation } \\ \text { SP } & \text { Signal peptide }\end{array}$




\section{References}

1. Roberts, D.L.; Dixon, K.W. Orchids. Curr. Biol. 2008, 18, 325-329. [CrossRef] [PubMed]

2. Wong, S.M. Orchid viruses-A compendium. In Orchid Biology VIII: Reviews and Perspectives; Kull, T., Arditti, J., Eds.; Kluwer Academic Publishers: Dordrecht, The Netherlands, 2002; pp. 505-546.

3. Chen, S.; Liu, Z.; Zhu, G.; Lang, K.; Ji, Z.; Luo, Y.; Jin, X.; Cribb, P.J.; Wood, J.J.; Gale, S.W.; et al. Orchidaceae. In Flora of China; Wu, Z.Y., Raven, P.H., Hong, D., Eds.; Science Press: Beijing, China; Missouri Botanical Garden Press: St. Louis, MO, USA, 2009; pp. 211-235.

4. Cribb, P.J. Subtribe Polystachyinae, Taxonomic notes. In Genera Orchidacearum, Volume 6: Epidendroideae (Part 3); Pridgeon, A.M., Cribb, P.J., Chase, M.W., Rasmussen, F.N., Eds.; Oxford University Press: Oxford, UK, 2014; p. 544.

5. Tuhid, N.H.; Abdullah, N.E.; Khairi, N.M.; Saaid, M.F.; Shahrizam, M.S.B.; Hashim, H. A statistical approach for orchid disease identification using RGB color. In Proceedings of the 2012 IEEE Control and System Graduate Research Colloquium, Shah Alam, Selangor, Malaysia, 16-17 July 2012; pp. 382-385.

6. Koh, K.W.; Lu, H.C.; Chan, M.T. Virus resistance in orchids. Plant Sci. 2014, 228, 26-38. [CrossRef]

7. Lim, S.T.; Wong, S.M.; Goh, C.J. Elimination of Cymbidium mosaic virus and Odontoglossum ringspot virus from orchids by meristem culture and thin section culture with chemotherapy. Ann. Appl. Biol. 1993, 122, 289-297. [CrossRef]

8. Panattoni, A.; Luvisi, A.; Triolo, E. Elimination of viruses in plants: Twenty years of progress. Span. J. Agri. Res. 2013, 1, 173-188.

9. Gurr, S.J.; Rushton, P.J. Engineering plants with increased disease resistance: What are we going to express? Trends Biotechnol. 2005, 23, 275-282. [CrossRef]

10. Pavan, S.; Jacobsen, E.; Visser, R.G.; Bai, Y. Loss of susceptibility as a novel breeding strategy for durable and broad-spectrum resistance. Mol. Breed. 2010, 25, 1. [CrossRef]

11. Collinge, D.B.; Jørgensen, H.J.; Lund, O.S.; Lyngkjær, M.F. Engineering pathogen resistance in crop plants: Current trends and future prospects. Ann. Rev. Phytopathol. 2010, 48, 269-291. [CrossRef]

12. Dong, X. NPR1, all things considered. Curr. Opin. Plant Boil. 2004, 7, 547-552. [CrossRef]

13. Hao, L.; Zhao, Y.; Jin, D.; Zhang, L.; Bi, X.; Chen, H.; Xu, Q.; Ma, C.; Li, G. Salicylic acid-altering Arabidopsis mutants response to salt stress. Plant Soil 2012, 354, 81-95. [CrossRef]

14. Jayakannan, M.; Bose, J.; Babourina, O.; Shabala, S.; Massart, A.; Poschenrieder, C.; Rengel, Z. The NPR1-dependent salicylic acid signaling pathway is pivotal for enhanced salt and oxidative stress tolerance in Arabidopsis. J. Exp. Bot. 2015, 66, 1865-1875. [CrossRef]

15. Liu, G.; Holub, E.B.; Alonso, J.M.; Ecker, J.R.; Fobert, P.R. An Arabidopsis NPR1-like gene, NPR4, is required for disease resistance. Plant J. 2005, 41, 304-318. [CrossRef] [PubMed]

16. Mou, Z.; Fan, W.; Dong, X. Inducers of plant systemic acquired resistance regulate NPR1 function through redox changes. Cell 2003, 113, 935-944. [CrossRef]

17. Sandhu, D.; Tasma, I.M.; Frasch, R.; Bhattacharyya, M.K. Systemic acquired resistance in soybean is regulated by two proteins, orthologous to Arabidopsis NPR1. BMC Plant Boil. 2009, 9, 105. [CrossRef] [PubMed]

18. Mishina, T.E.; Zeier, J. Pathogen-associated molecular pattern recognition rather than development of tissue necrosis contributes to bacterial induction of systemic acquired resistance in Arabidopsis. Plant J. 2007, 50, 500-513. [CrossRef] [PubMed]

19. Durrant, W.E.; Dong, X. Systemic acquired resistance. Annu. Rev. Phytopathol. 2004, 42, 185-209. [CrossRef] [PubMed]

20. Altenbach, D.; Robatzek, S. Pattern recognition receptors: From the cell surface to intracellular dynamics. Mol. Plant Microbe In. 2007, 20, 1031-1039. [CrossRef]

21. Bigeard, J.; Colcombet, J.; Hirt, H. Signaling mechanisms in pattern-triggered immunity (PTI). Mol. Plant 2015, 8, 521-539. [CrossRef]

22. Sticher, L.; Mauch-Mani, B.; Métraux, A.J. Systemic acquired resistance. Annu. Rev. Phytopathol. 1997, 35, 235-270. [CrossRef]

23. Loake, G.; Grant, M. Salicylic acid in plant defence-The players and protagonists. Curr. Opin. Plant Biol. 2007, 10, 466-472. [CrossRef]

24. Cao, H.; Bowling, S.A.; Gordon, A.S.; Dong, X. Characterization of an Arabidopsis mutant that is nonresponsive to inducers of systemic acquired resistance. Plant Cell 1994, 6, 1583-1592. [CrossRef] 
25. Chen, J.; Lu, H.; Chen, C.; Hsu, H.F.; Chen, H.H.; Yeh, H.H. The NPR1 ortholog PhaNPR1 is required for the induction of PhaPR1 in Phalaenopsis aphrodite. Bot. Stud. 2013, 54, 31. [CrossRef]

26. Lu, H.; Hsieh, M.H.; Chen, C.E.; Chen, H.H.; Wang, H.I.; Yeh, H.H. A high-throughput virus-induced gene-silencing vector for screening transcription factors in virus-induced plant defense response in orchid. Mol. Plant Microbe In. 2012, 25, 738-746. [CrossRef]

27. Cao, H.; Li, X.; Dong, X. Generation of broad-spectrum disease resistance by overexpression of an essential regulatory gene in systemic acquired resistance. Proc Natl. Acad. Sci. USA 1998, 95, 6531-6536. [CrossRef]

28. Grant, M.; Lamb, C. Systemic immunity. Curr. Opin. Plant Biol. 2006, 9, 414-420. [CrossRef]

29. Wu, Y.; Zhang, D.; Chu, J.Y.; Boyle, P.; Wang, Y.; Brindle, I.D.; Luca, V.D.; Després, C. The Arabidopsis NPR1 protein is a receptor for the plant defense hormone salicylic acid. Cell Rep. 2012, 1, 639-647. [CrossRef]

30. Kinkema, M.; Fan, W.; Dong, X. Nuclear localization of NPR1 is required for activation of PR gene expression. Plant Cell 2000, 12, 2339-2350. [CrossRef]

31. Beltagi, M.S. Exogenous ascorbic acid (vitamin C) induced anabolic changes for salt tolerance in chick pea (Cicer arietinum L.) plants. Afr. J. Plant Sci. 2008, 2, 118-123.

32. Barbetti, M.J.; Banga, S.S.; Salisbury, P.A. Challenges for crop production and management from pathogen biodiversity and diseases under current and future climate scenarios-case study with oilseed Brassicas. Field Crop. Res. 2012, 127, 225-240. [CrossRef]

33. Silva, K.J.P.; Mahna, N.; Mou, Z.; Folta, K.M. NPR1 as a transgenic crop protection strategy in horticultural species. Horti. Res. 2018, 5, 15. [CrossRef]

34. Chern, M.S.; Fitzgerald, H.A.; Yadav, R.C.; Canlas, P.E.; Dong, X.; Ronald, P.C. Evidence for a disease-resistance pathway in rice similar to the NPR1-mediated signaling pathway in Arabidopsis. Plant J. 2001, 27, 101-113. [CrossRef]

35. Lin, W.; Lu, C.; Wu, J.; Cheng, M.; Lin, Y.; Yang, N.; Black, L.; Green, S.K.; Wang, J.F.; Cheng, C.P. Transgenic tomato plants expressing the Arabidopsis NPR1 gene display enhanced resistance to a spectrum of fungal and bacterial diseases. Transgenic Res. 2004, 13, 567-581. [CrossRef]

36. Liu, Q.; Xue, Q. Computational identification of novel PR-1-type genes in Oryza sativa. J. Genetics 2006, 85, 193. [CrossRef]

37. Zhang, X.; Francis, M.I.; Dawson, W.O.; Graham, J.H.; Orbović, V.; Triplett, E.W.; Mou, Z. Over-expression of the Arabidopsis NPR1 gene in citrus increases resistance to citrus canker. Eur. J. Plant Pathol. 2010, 128, 91-100. [CrossRef]

38. Cheng, Y.; Zhang, H.; Yao, J.; Wang, X.; Xu, J.; Han, Q.; Wei, G.; Huang, L.; Kang, Z. Characterization of non-host resistance in broad bean to the wheat stripe rust pathogen. BMC Plant Biol. 2012, 12, 96. [CrossRef]

39. Quilis, J.; Peñas, G.; Messeguer, J.; Brugidou, C.; San Segundo, B. The Arabidopsis AtNPR1 inversely modulates defense responses against fungal, bacterial, or viral pathogens while conferring hypersensitivity to abiotic stresses in transgenic rice. Mol. Plant Microbe In. 2008, 21, 1215-1231. [CrossRef]

40. Wally, O.; Jayaraj, J.; Punja, Z.K. Broad-spectrum disease resistance to necrotrophic and biotrophic pathogens in transgenic carrots (Daucus carota L.) expressing an Arabidopsis NPR1 gene. Planta 2009, 231, 131-141. [CrossRef]

41. Backer, R.; Naidoo, S.; van den Berg, N. The nonexpressor of pathogenesis-related genes 1 (NPR1) and related family: Mechanistic insights in plant disease resistance. Front. Plant Sci. 2019, 10, 102. [CrossRef] [PubMed]

42. Xu, Y.Q.; Wang, H.; Qin, R.L.; Fang, L.J.; Liu, Z.; Yuan, S.S.; Ji, X.L. Characterization of NPR1 and NPR4 genes from mulberry (Morus multicaulis) and their roles in development and stress resistance. Physiol. Plant. 2019, 167, 302-316. [CrossRef]

43. Ding, Y.; Sun, T.; Ao, K.; Peng, Y.; Zhang, Y.; Li, X.; Zhang, Y. Opposite roles of salicylic acid receptors NPR1 and NPR3/NPR4 in transcriptional regulation of plant immunity. Cell 2018, 173, 1454-1467. [CrossRef]

44. Bari, R.; Jones, J.D. Role of plant hormones in plant defence responses. Plant Mol. Biol. 2009, 69, 473-488. [CrossRef]

45. Rejeb, I.; Pastor, V.; Mauch-Mani, B. Plant responses to simultaneous biotic and abiotic stress: Molecular mechanisms. Plants 2014, 3, 458-475. [CrossRef]

46. Verma, V.; Ravindran, P.; Kumar, P.P. Plant hormone-mediated regulation of stress responses. BMC Plant Biol. 2016, 16, 86. [CrossRef]

47. Kollist, H.; Zandalinas, S.I.; Sengupta, S.; Nuhkat, M.; Kangasjärvi, J.; Mittler, R. Rapid responses to abiotic stress: Priming the landscape for the signal transduction network. Trends Plant Sci. 2019, 24, 25-37. [CrossRef] 
48. Zhang, Y.; Fan, W.; Kinkema, M.; Li, X.; Dong, X. Interaction of NPR1 with basic leucine zipper protein transcription factors that bind sequences required for salicylic acid induction of the PR-1 gene. Proc. Natl. Aca. Sci. USA 1999, 96, 6523-6528. [CrossRef]

49. Després, C.; Chubak, C.; Rochon, A.; Clark, R.; Bethune, T.; Desveaux, D.; Fobert, P.R. The Arabidopsis NPR1 disease resistance protein is a novel cofactor that confers redox regulation of DNA binding activity to the basic domain/leucine zipper transcription factor TGA1. Plant Cell 2003, 15, 2181-2191. [CrossRef]

50. Fan, W.; Dong, X. In vivo interaction between NPR1 and transcription factor TGA2 leads to salicylic acid-mediated gene activation in Arabidopsis. Plant Cell 2002, 14, 1377-1389. [CrossRef] [PubMed]

51. Choi, J.; Huh, S.U.; Kojima, M.; Sakakibara, H.; Paek, K.H.; Hwang, I. The cytokinin-activated transcription factor ARR2 promotes plant immunity via TGA3/NPR1-dependent salicylic acid signaling in Arabidopsis. Dev. Cell 2010, 19, 284-295. [CrossRef]

52. Choudhury, F.K.; Rivero, R.M.; Blumwald, E.; Mittler, R. Reactive oxygen species, abiotic stress and stress combination. Plant J. 2017, 90, 856-867. [CrossRef] [PubMed]

53. Kovacs, I.; Durner, J.; Lindermayr, C. Crosstalk between nitric oxide and glutathione is required for nonexpressor of pathogenesis-related genes 1 (NPR 1)-dependent defense signaling in Arabidopsis thaliana. New Phytol. 2015, 208, 860-872. [CrossRef] [PubMed]

54. Mehdy, M.C. Active oxygen species in plant defense against pathogens. Plant Physiol. 1994, $105,467$. [CrossRef] [PubMed]

55. Hernández, J.A.; Rubio, M.; Olmos, E.; Ros-Barceló, A.; Martínez-Gómez, P. Oxidative stress induced by long-term plum pox virus infection in peach (Prunus persica). Physiol. Plant. 2004, 122, 486-495. [CrossRef]

56. Ren, R.; Yin, J.; Zheng, H.; Wang, T.; Liu, S.; Karthikeyan, A.; Yang, Q.; Gao, L.; Zhi, H.; Li, K. Characterization of broad-spectrum resistance to Soybean mosaic virus in soybean [Glycine max (L.) Merr.] cultivar 'RN-9'. Plant Breed. 2018, 137, 605-613. [CrossRef]

57. Hu, W.W.; Wong, S.M.; Loh, C.S.; Goh, C.J. Synergism in replication of cymbidium mosaic potexvirus (CymMV) and odontoglossum ringspot tobamovirus (ORSV) RNA in orchid protoplasts. Arch. Virol. 1998, 143, 1265-1275. [CrossRef] [PubMed]

58. Lee, K.C.; Koh, A.; Loh, C.S.; Wong, S.M. Cucurbit protoplast isolation for the study of plant virus replication. J. Virology. Methods 2001, 91, 21-27. [CrossRef]

59. Liang, X.; Ding, S.; Wong, S. Development of a kenaf (Hibiscuscannabinus L.) protoplast system for a replication study of Hibiscus chlorotic ringspot virus. Plant Cell Rep. 2002, 20, 982-986. [CrossRef]

60. Chen, S.; Tao, L.; Zeng, L.; Vega-Sanchez, M.E.; Umemura, K.; Wang, G. A highly efficient transient protoplast system for analyzing defence gene expression and protein-protein interactions in rice. Mol. Plant Pathol. 2006, 7, 417-427. [CrossRef]

61. Raghupathy, M.B.; Griffiths, J.S.; Stobbs, L.W.; Brown, D.C.; Brandle, J.E.; Wang, A. Transfection of Arabidopsis protoplasts with a Plum pox virus (PPV) infectious clone for studying early molecular events associated with PPV infection. J. Virol. Methods 2006, 136, 147-153. [CrossRef]

62. Babu, M.; Griffiths, J.S.; Huang, T.S.; Wang, A. Altered gene expression changes in Arabidopsis leaf tissues and protoplasts in response to Plum pox virus infection. BMC Genom. 2008, 9, 325. [CrossRef]

63. Iskra-Caruana, M.L.; Baurens, F.C.; Gayral, P.; Chabannes, M. A four-partner plant-virus interaction: Enemies can also come from within. Mol. Plant Microbe In. 2010, 23, 1394-1402. [CrossRef]

64. Yang, F.; Zhu, G. Digital gene expression analysis based on de novo transcriptome assembly reveals new genes associated with floral organ differentiation of the orchid plant Cymbidium ensifolium. PLoS ONE 2015, 10, e0142434. [CrossRef]

65. Yang, F.; Zhu, G.; Wang, Z.; Liu, H.; Xu, Q.; Zhao, C. Integrated mRNA and microRNA transcriptome variations in the multi-tepal mutant provide insights into the floral patterning of the orchid Cymbidium goeringii. BMC Genom. 2017, 18, 367. [CrossRef] [PubMed]

66. Tamura, K.; Peterson, D.; Peterson, N.; Stecher, G.; Nei, M.; Kumar, S. MEGA5: Molecular evolutionary genetics analysis using maximum likelihood, evolutionary distance, and maximum parsimony methods. Mol. Biol. Evol. 2011, 28, 2731-2739. [CrossRef] [PubMed]

67. Yoo, S.D.; Cho, Y.H.; Sheen, J. Arabidopsis mesophyll protoplasts: A versatile cell system for transient gene expression analysis. Nature Prot. 2007, 2, 1565-1572. [CrossRef] [PubMed]

68. Lin, H.Y.; Chen, J.C.; Fang, S.C. A protoplast transient expression system to enable molecular, cellular, and functional studies in Phalaenopsis orchids. Front. Plant Sci. 2018, 9, 843. [CrossRef] [PubMed] 
69. Jones, K.H.; Senft, J.A. An improved method to determine cell viability by simultaneous staining with fluorescein diacetate-propidium iodide. J. Histochem. Cytochem. 1985, 33, 77-79. [CrossRef]

70. Hwang, S.H.; Hwang, D.J. Isolation and characterization of the rice NPR1 promoter. Plant Biotechnol. Rep. 2010, 4, 29-35. [CrossRef]

71. Rui, R.; Liu, S.; Karthikeyan, A.; Wang, T.; Niu, H.; Yin, J.; Yang, Y.; Wang, L.; Yang, Q.; Zhi, H. Fine-mapping and identification of a novel locus Rsc15 underlying soybean resistance to Soybean mosaic virus. Theor. Appl. Genet. 2017, 130, 2395-2410. [CrossRef]

72. Yu, H.H.; Wong, S.M. A DNA clone encoding the full-length infectious genome of Odontoglossum ringspot tobamovirus and mutagenesis of its coat protein gene. Arch. Virol. 1998, 143, 163-171. [CrossRef]

73. Otto, F. DAPI staining of fixed cells for high-resolution flow cytometry of nuclear DNA. Methods Cell Biol. 1990, 33, 105-110.

74. Sherpa, A.R.; Hallan, V.; Pathak, P.; Zaidi, A.A. Characterization of the coat protein gene of Cymbidium mosaic virus isolates from India. J. Phytopathol. 2006, 154, 275-280. [CrossRef]

(C) 2020 by the authors. Licensee MDPI, Basel, Switzerland. This article is an open access article distributed under the terms and conditions of the Creative Commons Attribution (CC BY) license (http://creativecommons.org/licenses/by/4.0/). 